\title{
Legal Protection against Women Which Do Criminal Actions of Abortion from Victims of Rape for Justice
}

\author{
Farida $^{*)}$ and Sri Kusriyah ${ }^{* *}$ \\ ${ }^{*}$ Prosecutors at the Central Java High Court at JIn. Pahlawan No. 14, Semarang \\ City E-mail: faridaruth@gmail.com \\ ${ }^{* *}$ Faculty of Law, Universitas Islam Sultan Agung Semarang, Indonesia
}

\begin{abstract}
This study aims to identify and describe the legal protection of women perpetrators of the crime of abortion, victims of rape based on positive law in Indonesia in order to realize justice. This study uses a normative juridical approach, which is descriptive analysis. The data used is secondary data obtained through library research, which is then analyzed qualitatively. The results of this study are legal protection for women perpetrators of abortion, victims of rape based on positive law in Indonesia to achieve justice that in Article 48 of the Criminal Code that the perpetrator's actions are committed due to coercion, then they will not be convicted. The perpetrator was released from punishment on the grounds of forgiveness, whereas in the Republic of Indonesia Act No. 36 of 2009, that abortion is allowed due to indications of a medical emergency that threatens the life of the mother and pregnancy due to rape, given the trauma caused by rape that must be experienced by women who are victims of rape is very severe.

Keywords: Abortion; Justice; Rape Victims; Women; Legal Protection.
\end{abstract}

\section{Introduction}

Sexual crimes or crimes are currently rampant in Indonesia. Perpetrators are not only adults, but also teenagers. This sexual crime is a scourge for women, like the terror that always follows women's existence. Perpetrators don't even care to kill their victims for the sake of instant gratification.

Girls to adult women are all potential victims of sexual violence. Sexual violence is an act, whether in the form of words or actions by a person to control or manipulate another person and to make the victim engage in sexual activity that the perpetrator does not want.

Sexual violence is more common among women, which is due to the stigma held by some in society that women are weak creatures, and those who deserve to be blamed for experiencing sexual violence against them. The society considers that women who wear uncovered clothes deserve violence because they are the ones who invite crime. One form of sexual violence that often occurs in Indonesia is the crime of rape.

World Health Organization (WHO) defines rape as penetration of the vagina or anus using the penis, other body parts or an object by means of force, whether physical or non-physical. The Inter-national Criminal Court for Rwanda in 1998 defined rape as a physical invasion of a sexual nature committed against a human being in coercive circumstances or environments. ${ }^{1}$

\footnotetext{
1 Siska Lis Sulistiani, 2016, Kejahatan \& Penyimpangan Seksual Dalam Perspektif Hukum Islam dan Hukum Positif Indonesia, First Printing, Nuansa Aulia, Bandung, p. 91.
} 
Rape is a crime that often occurs in people's lives. Rape is included in sexual crime as an act or action that tends to lead to things that are sexual in nature. Rape can occur personally and in society (community) where the victim is always a woman, then seen from the age of the victim, rape can occur in adults and younger children. ${ }^{2}$ Rape is an act of sexual desire by a man against a woman in a way that is moral or violates the applicable law. ${ }^{3}$

The main characteristic of the act of rape is that rape is not primarily an expression of aggressiveness (violence) of sexuality (the aggressive expression of aggression), but is a sexual expression of aggressiveness (violence), some even say rape. Including the category of sexually assaultive behavior or sexual coercion. ${ }^{4}$

In this crime of rape, the perpetrator is not only a person who has no family relationship with the victim, but also people who have family relations with the victim. Rape is carried out by using threats, physical force, or intimidation to induce sexual relations with another person against the will of that person (the victim).

The problems that occur to rape victims are not only sick because of physical injuries, but victims generally also experience psychological trauma, and victims do not immediately tell their family or other people the incident they experienced to help them to immediately take medical action using emergency contraception as an effort to prevent risks to the -pregnancy and/or report to the police. Victims generally feel afraid to reveal what happened to them. The victim will feel that he or she has damaged the good name of the family, so that the victim tends to do self-blaming which will only make the situation worse. This is what makes the victim shut herself off from telling the people around her rape for fear of receiving a bad label from the environment. ${ }^{5}$

An unwanted pregnancy is one of the consequences of the crime of rape, which causes the victim to become depressed. An unwanted pregnancy is a very traumatic event for a woman who is a victim of rape. The impact of the criminal act of rape that befell women who later become pregnant, where the unwanted pregnancy makes the woman feel depressed, and in the end she has an abortion.

It is necessary to respond wisely to abortion by women victims of rape. Basically, women who undergo abortion because of rape are victims of rape, so that from the very heavy impact of rape on women victims of rape, it is not appropriate and inappropriate for women victims of rape to be penalized for having had an abortion.

In the Criminal Code (KUHP), abortion is regulated in Article 283, Article 299, Article 346, Article 347, Article 348, Article 349, and Article 535. Based on these articles,

\footnotetext{
${ }^{2}$ Endang Kusnandar, Anis Mashdurohatun, and Siti Rodhiyah Dwi Istinah, March 2020, Protection Analysis Of Children Rights That Was Born From The Rape Causing (Study in State Court (PN) in ExResidency Cirebon Jurisdiction), Jurnal Daulat Hukum, Vol. 3 No. 1, Faculty of Law, Universitas Islam Sultan Agung, Semarang, p. 17.

${ }^{3}$ Ervin Faizal Nurdiansyah, September 2018, Application of Criminal Sanctions Against The Crime of Child Rape Linked with Article 82 of Act No. 35 of 2014 Concerning The Protection of Children, Jurnal Daulat Hukum, Vol. 1 No. 3, Faculty of Law, Universitas Islam Sultan Agung, Semarang, p. 733.

4 Rena Yulia, 2013, Viktomologi, Perlindungan Hukum Terhadap Korban Kejahatan, Graha IImu, Yogyakarta, p. 15 and 16.

${ }^{5}$ Riza Yuniar Sari, 2013, Aborsi Korban Perkosaan Perspektif Hukum Islam dan Hak Asasi Manusia, AlHukama, The Indonesian Journal of Islamic Family Law, Vol. 3, Sidoarjo, p. 49-50.
} 
lawsuits will be imposed on people who perform the abortion or people who help, either directly or indirectly. Abortion under the Criminal Code is prohibited, without exception.

In contrast to the regulation of abortion in the Republic of Indonesia Act No. 36 of 2009 concerning Health, which replaces the previous health law, namely the Republic of Indonesia Act No. 23 of 1992. In the Republic of Indonesia Act No. 36 of 2009, the issue of abortion gains legitimacy and affirmation. Explicitly, this Law contains articles regulating abortion. Even though the law prohibits abortion, in certain circumstances it is permissible.

The gap between legal norms relating to abortion which contains prohibitions and criminal sanctions and the abortion phenomenon which tends to increase in society clearly shows that there are many violations of the law regarding abortion in Indonesia. Therefore, the criminal law on abortion should be fairer to women by providing various solutions in the form of shelter (protection) that psychologically guarantees a sense of security for women who suffer from unwanted pregnancies, so that they do not take shortcuts by having a prohibited abortion by law in Indonesia. ${ }^{6}$

Women who have abortions because of rape are victims who must receive protection. In the framework of legal protection for victims, victim protection must be used as part of efforts to enforce criminal law as part of a social policy which is a joint effort to improve the welfare/social welfare policy and social defense policy that accommodates the rights of victims. ${ }^{7}$

The purpose of this research is to find out and examine the legal protection of women perpetrators of the crime of abortion, victims of rape, to achieve justice.

\section{Research Methods}

The type of research used in writing this legal journal is normative juridical. Normative juridical research is research that is focused on examining the application of the rules or norms in positive law, ${ }^{8}$ which in this case relates to legal protection of women perpetrators of the crime of abortion, victims of rape, to achieve justice. This research is descriptive analysis, because the researcher wishes to describe or describe the subject and object of the research, which then analyzes and finally draws conclusions from the results of the research. ${ }^{9}$ The data used in this research is secondary data. Secondary data is data obtained from library materials through library research, and this data is also obtained from agencies/institutions related to the purpose of this research. ${ }^{10}$ According to the data obtained during the research by reading library books, then analyzed. The analysis used in this research is qualitative data analysis.

\footnotetext{
${ }^{6}$ Tina Asmarawati, 2013, Hukum \& Abortus, First Edition, First Edition, Deepublish, Yogyakarta, p. 3.

${ }^{7}$ C. Maya Indah S., 2019, Perlindungan Korban, Suatu Perspektif Viktimologi dan Kriminologi, Second Edition, Third Edition, Kencana Prenada Media, Jakarta, p. 115.

8 Jhonny Ibrahim, 2011, Teori dan Metodologi Penelitian Hukum Normatif, Bayumedia, Malang, p. 295.

${ }^{9}$ Mukti Fajar ND and Yulianto Achmad, 2010, Dualisme Penelitian Hukum Normatif dan Empiris, Pustaka Pelajar,Yogyakarta, p. 183.

${ }^{10}$ Soeratno and Lincolin Arsyad, 2003, Metodologi Penelitian Untuk Ekonomi Dan Bisnis, UPP AMP YKPN, Yogyakarta, p. 173.
} 


\section{Result and Discussion}

Abortion or commonly referred to as abortion, entered human civilization because women did not want the pregnancy. Unwanted pregnancy, which then leads to abortion, is a serious problem in many developing countries, including Indonesia. The causes of unwanted pregnancy and abortion are victims of rape, lack of knowledge about reproductive health, and contraceptive failure. ${ }^{11}$

The popular term for abortion is an abortion. From a legal point of view, aborting the womb is not exactly the same as the practice of abortion because from a legal (criminal) point of view, there are 2 (two) forms of action, namely: ${ }^{12}$

- The act of aborting the womb (afdrijven);

- The deadly deeds (dood'doen) of the womb.

According to Eastman, abortion is a state of termination of a pregnancy in which the fetus is not able to stand alone outside the uterus. It cannot be interpreted if the fetus weighs between 400-1000 grams or a pregnancy of less than 28 weeks. ${ }^{13}$ Soekidjo Notoatmodjo defined abortion as the premature release or release of the conception from the mother's womb. ${ }^{14}$ In other words, abortion is an "output" which is meant for the fetus to come out intentionally due to human intervention, either through mechanical means, drugs or other means. ${ }^{15}$

Abortion is the premature discharge or discharge of the product of conception from a mother's womb Abortion or abortion can occur spontaneously and artificial abortion. Spontaneous abortion is a natural mechanism for the release of an abnormal conception (miscarriage), while artificial abortion, also known as termination of pregnancy, has 2 (two) types, namely: ${ }^{16}$ Fiirst, Legal; Legal abortion is performed by competent health or medical personnel based on medical indications, and with the consent of the pregnant mother and/or husband. Legal abortion is often called artificial abortion or abortion with medical indications. However, not every abortion that has medical indications can be artificial abortion. Other requirements that must be met by an abortion are: Abortion is only performed as a therapeutic measure; Approved in writing by two competent doctors; Conducted at a health care facility recognized by a legal authority; Second, Illegal; Illegal abortion is performed by incompetent health or medical personnel, through non-medical means (massage, herbal medicine or ingredients), with or without the consent of the pregnant woman and/or her husband. Illegal abortions are often performed by competent medical personnel, but who have no medical indication.

\footnotetext{
${ }^{11}$ Marmi, 2014, Etika Profesi Bidan, First Edition, Pustaka Pelajar, Yogyakarta, p. 62.

12 Ari Yunanto and Helmi, 2010, Hukum Pidana Malpraktik Medik, Tinjauan dan Perspektif Medikolegal, First Edition, ANDI, Yogyakarta, p. 59.

13 Yulia Fauziyah and Cecep Triwibowo, 2013, Medical Book, Bioteknologi Kesehatan Dalam Perspektif Etika dan Hukum, First Edition, Nuha Medika, Yogyakarta, p. 144.

${ }^{14}$ Trini Handayani and Aji Mulyana, 2019, Tindak Pidana Aborsi, First Printing, Index, Jakarta, p. 34.

15 Eka Damayanti and Aryani Witasari, December 2019, Legal Protection from Provocate Abortion Against the Child Conceived Because Rape (Case Study on Jurisdiction Ex Residency of Cirebon), Jurnal Daulat Hukum, Vol. 2 No. 4, Faculty of Law Universitas Islam Sultan Agung, Semarang, p. 602.

${ }^{16}$ Soekidjo Notoatmodjo, 2010, Etika \& Hukum Kesehatan, First Edition, Rineka Cipta, Jakarta, p. 135 and 136.
} 
In Indonesian society, abortion is prohibited or complicated by law. Pregnant women who seek help from a traditional birth attendant or other incompetent person can cause complications such as infection, heavy bleeding, infertility, and even the death of the woman concerned. The woman can seek the help of a specialist doctor, but because of a prohibited act that can pose a risk to the doctor, the woman will be subject to very expensive payments. ${ }^{17}$

One of the reasons that a pregnant woman has an abortion/abortion is because of pregnancy due to rape. A pregnant woman victim of rape can choose one of two alternatives to respond to her condition, continue an unwanted pregnancy or have an abortion. If she chooses to continue her pregnancy, then she must be ready to become a single parent without a husband. In this case, the role of families and residents around the place of residence to participate in maintaining and maintaining the stability of the prospective mother's soul is needed so that the pregnancy and childbirth period can be lived safely. Sociologically, this is a tough choice considering the socio-cultural conditions of the Indonesian people who still look down on even taboo, a woman who is pregnant or has a child without a legal husband. ${ }^{18}$

With regard to abortion, the Indonesian people have recognized and accepted abortion, even though it is in a traditional way, such as the existence of traditional birth abortions and the circulation of various types of concoctions or concoctions in the community. The practice of abortion by the Dukun is generally done in a very simple way, and it is accepted by the community as a matter of course (in the sense that it does not matter). However, in its development, abortion is no longer accepted as a common thing, but the practice of abortion has begun to be questioned. ${ }^{19}$

Abortions performed by women victims of rape are carried out because of compulsion, making women victims of rape who are convicted must accept any risk. Women victims of rape are victims of crime who also need legal protection. Law is a rule, norm, code of conduct, or statutory regulation, which if violated will be subject to sanctions, ${ }^{20}$ besides that, law also functions as an instrument of legal protection for legal subjects. ${ }^{21}$

Abortion-related regulations contained in the Criminal Code (KUHP) prohibit abortion for any reason. For example, Article 349 of the Criminal Code states that if a doctor, midwife or medicine worker assists in committing a crime under Article 346 (abortion), or commits or assists in committing one of the crimes described in Article 347 and Article 348 (abortion), then the punishment specified in The article can be increased by one third and can be deprived of the right to carry out a livelihood in which the crime was committed. If this Article is absolutely applicable, then all doctors can be subject to criminal penalties.

\footnotetext{
${ }^{17}$ Tina Asmarawati, op.cit., P. 2.

18 Aroma Elmina Martha and Singgih Sulaksana, 2019, Legalisasi Aborsi, First Printing, UII Press, Yogyakarta, p. 38.

19 Marcel Seran and Anna Maria Wahyu Setyowati, 2010, Dilema Etika dan Hukum Dalam Pelayanan Medis, First Edition, Mandar Maju, Bandung, p. 58.

20 Jawade Hafidz Arsyad and Dian Karisma, 2018, Sentralisasi Birokrasi Pengadaan Barang \& Jasa Pemerintah, First Printing, Sinar Grafika, Jakarta, p. 63.

21 Jawade Hafidz Arsyad, 2013, Korupsi Dalam Perspektif HAN (Hukum Administrasi Negara), First Printing, Sinar Grafika, Jakarta, p. 200.
} 
The legal protection of women victims of rape who have had an abortion against the threat of the crime of abortion, in the Criminal Code is based on Article 48 of the Criminal Code, namely: "Whoever commits an act due to the influence of force (overmacht), is not punished". The provisions of Article 48 of the Criminal Code are applied to rape victims who commit an abortion by releasing them from punishment on the grounds of forgiveness. This means that the perpetrator's actions remain against the law, it's just that the mistakes made have excuses.

Along with the development of the medical/medical world, a method or method was found to detect fetal development, disease/abnormalities in the fetus, including indications of medical emergencies in pregnant women, so that the Criminal Code which is a legacy of Dutch colonialism is considered to be out of date.

Law of the Republic of Indonesia Number 36 of 2009 concerning Health is a legal renewal of the previous law, namely Law of the Republic of Indonesia Number 23 of 1992. One of the legal reforms in Law of the Republic of Indonesia Number 36 of 2009 is the addition of an exception to the prohibition of abortion. . Exceptions to the prohibition of abortion, apart from indications of a medical emergency that threatens the life of the mother, an article is also added because of pregnancy due to rape.

After the issuance of Law of the Republic of Indonesia Number 36 of 2009, a derivative regulation was issued to implement the law, namely Government Regulation Number 61 of 2014 concerning Reproductive Health, which is then regulated in more detail in its implementation in the Minister of Health Regulation Number 71 of 2014 and Minister of Health Regulation Number 3 of 2016.

The provisions for regulating abortion in Act No. 36 of 2009 concerning Health are set out in Article 75, Article 76, and Article 77, as follows: Article 75 Law of the Republic of Indonesia Number 36 of 2009

(1) Everyone is prohibited from having an abortion;

(2) The prohibition as referred to in paragraph (a) may be exempted based on: (a) An indication of a medical emergency detected from an early age in pregnancy, whether it is life threatening to the mother and/or fetus, who is suffering from serious genetic diseases and/or congenital defects, or that cannot be repaired so that it makes it difficult for the baby to live outside the confinement; or (b) Pregnancy due to rape that can cause psychological trauma for the victim of rape.

(3) Actions as referred to in paragraph (2) can only be carried out after going through pre-action counseling and/or advice and ended with post-action counseling carried out by a competent and authorized counselor;

(4) Further provisions regarding indications of medical emergencies and rape as referred to in paragraph (2) and paragraph (3) shall be regulated in a Government Regulation.

Article 76 of Law of the Republic of Indonesia Number 36 of 2009, Abortion as referred to in Article 75 can only be performed:

a. Before 6 (six) weeks of pregnancy, counting from the first day of last menstrual period, except in the case of a medical emergency;

b. By health workers who have the skills and authority who have a certificate stipulated by the minister;

c. With the consent of the pregnant mother concerned; 
d. With the husband's permission, except for the victim of rape; and

e. Health service providers who meet the requirements set by the Minister.

Article 77 Law of the Republic of Indonesia Number 36 of 2009, The government is obliged to protect and prevent women from abortion as referred to in Article 75 paragraph (2) and paragraph (3) which are of no quality, insecure, and irresponsible and contrary to religious norms and provisions of laws and regulations.

For women who have an abortion because of rape, they should get good treatment because these women are actually victims of sexual violence. As stated in Article 29 of Government Regulation Number 61 of 2014 that:

(1) Victims of sexual violence must be handled in a multidisciplinary manner by paying attention to legal, security and safety aspects, as well as physical, mental and sexual health;

(2) The handling of legal, security and safety aspects as referred to in paragraph (1), includes:

a. Efforts to protect and save victims;

b. Forensic efforts to prove; and

c. Identify the perpetrator.

(3) Treatment of physical, mental, and sexual health aspects of victims of sexual violence as referred to in paragraph (1), includes:

a. Physical, mental, and supporting examinations;

b. wound and/or injury treatment;

c. Prevention and/or handling of sexually transmitted diseases;

d. Prevention and/or treatment of pregnancy;

e. Psychiatric therapy and psychotherapy; and

f. Psychosocial rehabilitation.

(4) Provisions regarding the handling of victims of sexual violence are carried out in accordance with statutory provisions.

Abortions that are performed as a result of rape can only be performed by doctors who are eligible for an abortion, as stated in Article 12 of the Minister of Health Regulation Number 3 of 2016 concerning Training and Implementation of Abortion Services for Indications of Medical Emergencies and Pregnancy Due to Rape, that :

(1) Abortion services for indications of medical emergencies and pregnancy due to rape must be carried out safely, with quality and responsibly;

(2) Safe, quality, and responsible abortion services, including:

a. Performed by doctors in accordance with professional standards, service standards and standard operating procedures;

b. At the request or consent of the pregnant woman concerned;

c. With the husband's permission, except for the victim of rape;

d. Not discriminatory; and

e. Not prioritizing material rewards.

(3) In the event that the husband's license as referred to in paragraph (1) letter c cannot be fulfilled, the consent can be given by the family of the pregnant woman concerned.

The practice of abortion that is against the laws and regulations is illegal abortion. Criminal sanctions for perpetrators of illegal abortion are regulated in Article 194 of 
Republic of Indonesia Act No. 36 of 2009. Article 194 of Republic of Indonesia Act No. 36 of 2009 can ensnare doctors and/or health workers who deliberately carry out illegal abortions or women who deliberately carry out illegal abortions, did it on purpose. Article 194 of the Republic of Indonesia Act No. 36 of 2009 states that: "Every person who deliberately has an abortion that does not comply with the provisions referred to in Article 75 paragraph (2) shall be punished with imprisonment of up to 10 years and a maximum fine of IDR 1,000,000. 000.00 (one billion rupiah)".

In cases of abortion in women victims of rape, the act of having an abortion has its own exceptions and considerations, remembering that the trauma caused by rape that must be experienced by women victims of rape is very severe, and the victim is forced to do it or because of the force of force, so it is necessary to obtain legal protection not criminalizing women victims of rape. As a form of legal protection for victims, of course the rights or interests of victims must be restored. ${ }^{22}$

The presence of the state to protect women as mandated by the constitution to protect the entire Indonesian nation is a task that must be carried out by the government whose obligations are the basic rights of citizens without exception. ${ }^{23}$ In principle, the state prohibits abortion. In different conditions due to the coercion of the perpetrator's will, a victim of rape will suffer physically, mentally, and socially. Pregnancy as a result of rape will aggravate the mental condition of the victim who had previously suffered severe trauma due to the incident. Heavy mental trauma will also have a negative impact on the development of the fetus the victim is carrying. The state must protect its citizens, in this case women who carry out abortions based on medical emergencies and the result of rape, as well as medical personnel (doctors) who perform them, Republic of Indonesia Act No. 36 of 2009 opens exceptions for abortion based on indications of medical emergencies and pregnancy due to rape.

\section{Closing}

Legal protection for women perpetrators of the crime of abortion, victims of rape, to achieve justice in Article 48 of the Criminal Code that the actions of the perpetrator were carried out because of coercion (Over-Macht), then they are not subject to punishment. The perpetrator was released from punishment on the grounds of forgiveness, whereas in Act No. 36 of 2009, abortion is allowed because of an indication of a life-threatening medical emergency and pregnancy due to rape, given the trauma resulting from rape that must be experienced by women victims of rape is very heavy.

It is necessary to have arrangements regarding restitution or compensation that must be borne by the perpetrator of rape and rehabilitation/assistance by competent experts (psychologists) to get rid of the trauma of the victim.

\footnotetext{
22 Hengki Irawan, Sri Endah Wahyuningsih, and Jawade Hafidz, December 2019, Legal Protection For Victims Of Traffic Violations That Lead To Death (Case Study On Police Traffic of Rembang), Jurnal Daulat Hukum, Vol. 2 No. 4, Faculty of Law, Universitas Islam Sultan Agung, Semarang, p. 490.

${ }^{23}$ Farhan Munirus Su'aidi and Abdullah Arief Cholil, December 2019, Law Protection on Wife Whose The Claims Fall Due To Husband Refuse His Recompensation On Implementing Of Divorce Pledge, Jurnal Daulat Hukum, Vol. 2 No. 4, Faculty of Law, Universitas Islam Sultan Agung, Semarang, p. 548.
} 


\section{References}

\section{Journal}

[1] Eka Damayanti and Aryani Witasari, December 2019, Legal Protection from Provocate Abortion Againts the Child Conceived Because Rape (Case Study on Jurisdiction Ex Residency of Cirebon), Jurnal Daulat Hukum, Vol. 2 No. 4, Faculty of Law, Universitas Islam Sultan Agung, Semarang.

[2] Endang Kusnandar, Anis Mashdurohatun, and Siti Rodhiyah Dwi Istinah, March 2020, Protection Analysis Of Children Rights That Was Born From The Rape Causing (Study in State Court (PN) in Ex-Residency Cirebon Jurisdiction), Jurnal Daulat Hukum, Vol. 3 No. 1, Faculty of Law, Universitas Islam Sultan Agung, Semarang.

[3] Ervin Faizal Nurdiansyah, September 2018, Application of Criminal Sanctions Against The Crime of Child Rape Linked with Article 82 of Act No. 35 of 2014 Concerning The Protection of Children, Jurnal Daulat Hukum, Vol. 1 No. 3, Faculty of Law, Universitas Islam Sultan Agung, Semarang.

[4] Farhan Munirus Su'aidi and Abdullah Arief Cholil, December 2019, Law Protection on Wife Whose The Claims Fall Due To Husband Refuse His Recompensation On Implementing Of Divorce Pledge, Jurnal Daulat Hukum, Vol. 2 No. 4, Faculty of Law, Universitas Islam Sultan Agung, Semarang.

[5] Hengki Irawan, Sri Endah Wahyuningsih, and Jawade Hafidz, December 2019, Legal Protection For Victims Of Traffic Violations That Lead To Death (Case Study On Police Traffic of Rembang), Jurnal Daulat Hukum, Vol. 2 No. 4, Faculty of Law, Universitas Islam Sultan Agung, Semarang.

[6] Riza Yuniar Sari, 2013, Aborsi Korban Perkosaan Perspektif Hukum Islam dan Hak Asasi Manusia, Al-Hukama, The Indonesian Journal of Islamic Family Law, Vol. 3, Sidoarjo.

\section{Books}

[1] Ari Yunanto and Helmi, 2010, Hukum Pidana Malpraktik Medik, Tinjauan dan Perspektif Medikolegal, First Edition, ANDI, Yogyakarta.

[2] Aroma Elmina Martha and Singgih Sulaksana, 2019, Legalisasi Aborsi, First Printing, UII Press, Yogyakarta.

[3] C. Maya Indah S., 2019, Perlindungan Korban, Suatu Perspektif Viktimo-logi dan Kriminologi, Third Edition, Kencana Prenada Media, Jakarta.

[4] Jawade Hafidz Arsyad and Dian Karisma, 2018, Sentralisasi Birokrasi Pengadaan Barang \& Jasa Pemerintah, First Edition, Sinar Grafika, Jakarta.

[5] ----------------, 2013, Korupsi Dalam Perspektif HAN (Hukum Admi-nistrasi Negara), First Printing, Sinar Grafika, Jakarta.

[6] Jhonny Ibrahim, 2011, Teori dan Metodologi Penelitian Hukum Normatif, Bayumedia, Malang.

[7] Marcel Seran and Anna Maria Wahyu Setyowati, 2010, Dilema Etika dan Hukum Dalam Pelayanan Medis, First Edition, Mandar Maju, Bandung.

[8] Marmi, 2014, Etika Profesi Bidan, First Edition, Pustaka Pelajar, Yogyakarta. 
[9] Mukti Fajar ND and Yulianto Achmad, 2010, Dualisme Penelitian Hukum Normatif dan Empiris, Pustaka Pelajar.

[10] Rena Yulia, 2013, Viktomologi, Perlindungan Hukum Terhadap Korban Kejahatan, Second Edition, Graha Ilmu, Yogyakarta.

[11] Siska Lis Sulistiani, 2016, Kejahatan \& Penyimpangan Seksual Dalam Perspektif Hukum Islam dan Hukum Positif Indonesia, First Printing, Nuansa Aulia, Bandung.

[12] Soekidjo Notoatmodjo, 2010, Etika \& Hukum Kesehatan, First Edition, Rineka Cipta, Jakarta.

[13] Soeratno and Lincolin Arsyad, 2003, Metodologi Penelitian Untuk Ekonomi Dan Bisnis, UPP AMP YKPN, Yogyakarta.

[14] Tina Asmarawati, 2013, Hukum \& Abortus, First Edition, First Edition, Deepublish, Yogyakarta.

[15] Trini Handayani and Aji Mulyana, 2019, Tindak Pidana Aborsi, First Printing, Index, Jakarta.

[16] Yulia Fauziyah and Cecep Triwibowo, 2013, Medical Book, Bioteknologi Kesehatan Dalam Perspektif Etika dan Hukum, First Edition, Nuha Medika, Yogyakarta. 